\section{Polish education}

\section{Threat of repressive new law}

THE current clampdown on the academic community in Poland could seriously imperil Polish hopes of regaining Most Favoured Nation status (MFN) with respect to the United States. Loss of MFN, as part of the package of sanctions imposed by the United States when General Jaruzelski imposed Martial Law in December 1981, has cost an estimated $\$ 50$ million in Poland's foreign trade earnings. Alleged government plans for the deployment of graduates, recently described by the underground Solidarity journal Tygodnik Mazowsze could well render this loss permanent.

According to Tygodnik Mazowsze, new legislation is being drafted jointly by the Ministry of Science and Higher Education and the Ministry of Education to ensure that all "graduates" work for ten years in the nationalized sector of the economy. "Graduates", the paper explains, apparently quoting from a leaked draft of the proposed legislation, includes all "Polish citizens who have completed basic vocational schooling, secondary vocational schooling of all types, higher education or who have taken PhDs abroad"'. If such persons fail to work in the nationalized sector for at least ten years after graduation, they may be asked to return to the treasury the cost of their education. As a corollary, "graduates" who have not completed this ten years' service, if going abroad, will be required to deposit the cost of their education as a guarantee of their return.

The last requirement appears to contravene the terms laid down in the US Senate by the Jackson-Vanik amendment (law $504 \mathrm{~A}$ ) of 1974, under which the US government is forbiden to grant MFN to any other government which requires intending emigrants to repay the cost of their education. According to the extracts of the draft

quoted in Tygodnik Mazowsze, implementation of the proposed law is expected to bring into the treasury several hundred million zloty a year from the contributions of graduates to the nationalized sector, as well as forfeited "guarantees".

In addition to the MFN problem, the implementation of the law could seriously damage Poland's international image. The new law would apply for 15 years after the end of their studies. This would seriously hamper the prospects of younger Polish scholars wishing to travel abroad for, even if they intended to return, they might not be able to pay the deposit. Linkage of higher education with employment contravenes the international human rights law. cover the trade-school sector could hit not only small craftsmen, but also the rundown private agricultural sector. Since 1980, the Polish government has given various grudging guarantees to the private farmers (who account for some 75 per cent of all Polish agriculture) that no attempts will be made to force them into the system of state and collective farms. The government has reluctantly agreed the principle of a scheme, proposed by the Catholic Church, to raise agricultural capital abroad and, according to Fr Alojzy Orszulik, the press spokesman of the Polish Catholic hierarchy, the government negotiators are about to "finish their work" on the plan. The rumoured new law would, however, mean that graduates of agricultural academies and agricultural secondary schools could return to their family's farms only in middle life. The foreign patrons of the Church scheme (who include the governments of the United States and the European Communities) may well be given pause.

The extension of the term "graduate" to

Vera Rich

\title{
Failure for West German Greens
}

LAST month's election in NordrheinWestfalen (NRW), the most populous state in the Federal Republic, was a great success for the Social Democratic Party (SPD). It comes exactly halfway through the legislative period of the Christian Democratic (CDU) Liberal (FDP) coalition government in Bonn and is widely regarded as a vote against the coalition policies. Equally important was the failure of the Green Party to obtain the 5 per cent vote necessary to win seats in the NRW parliament.

The Green Party fared less well than it had hoped in the election in Saarland three months earlier, where it obtained only $\mathbf{2 . 5}$ per cent of the votes. The $\mathbf{4 . 6}$ per cent in NRW was not a significant improvement on the result five years ago, when the Greens were a completely unknown factor.

Coalition with the SPD was made impossible by the Greens' determination that
NRW should withdraw completely from the nuclear industry. But, like the CDU/FDP in Bonn, the SPD in NRW has a strong interest in maintaining, among other nuclear power stations, the nuclear research centre at Jülich and the fast breeder reactor at Kalkar. It seems the FPD has now adopted enough of the political standpoint of the Green Party to weaken its appeal to ecologically minded voters.

Immediately after the election, an old quarrel broke out within the Green Party between the fundamentalists and realists. The former oppose all political compromises, while the latter strive to exert direct political influence. The difference between the two factions is so basic that it may splinter the Green Party. The three established parties may henceforth need take less notice of new radical ideas.

Jürgen Neffe
Indian cooking

\section{Chulhas win fair wind \\ New Delhi}

Chulhas (wood stoves) that do not emit smoke and use less wood are fast replac ing traditional cooking stoves in rural households, ushering in a "smokeless revolution" in India's countryside.

Some 800,000 smokeless chulhas have so far been installed and 5,000 villages have become smokeless in 15 months since the project was started by the Department of Non-conventional Energy Sources (DNES). The project has exceeded expectations, says DNES secretary Maheshwar Dayal, whose department has fixed a target of five million improved cooking stoves by 1990 .

About 40 per cent of all the energy in India is used for cooking food. The traditional woodstoves made of mud and brick in India's 112 million homes annually burn 133 million tonnes of firewood and over 200 million tonnes of cow-dung cake. But the stoves are so inefficient that rural women spend long hours collecting firewood. The improved cooking stoves, with a combustion efficiency of more than 15 per cent, have drastically cut down consumption of firewood. And because these stoves are designed to burn the fuel completely, the kitchens are smoke-free. Dayal says that smokeless chulhas introduced have saved 600,000 tonnes of firewood. By 1990 , the saving would be 4.2 million tonnes, valued at Rs 2,940 million ( $£ 210$ million).

Some 29 models of improved cooking stoves have been developed and introduced by social organizations and research institutions such as the Indian Institute of Technology (IIT) in Delhi, the Central Power Research Institute (CPRI) and the Indian Institute of Science (IIS) in Bangalore. The cooking stoves vary according to the region, type of food cooked and fuel used. But all new designs are tested and certified by testing and training centres at IIT, CPRI and the Punjab University of Agriculture in Chandigargh.

While fixed-type chulhas are installed by government agencies and voluntary organizations, portable models are marketed at prices ranging from Rs 38 to Rs 63 ( $£ 3$ to $£ 5$ ) by 12 private companies that have sprung up to cash in on the smokeless revolution. As an incentive to buyers, the government has abolished excise duty on fuel-efficient wood-burning stoves.

DNES has also developed community chulhas capable of cooking for up to 200 persons, with fuel efficiency as high as 35 per cent, recommended for hostels, hotels and canteens. The Tamil Nadu state government is planning to install the improved community chulhas in the 33,000 schools whose midday meal project is being threatened by firewood shortage.

K.S. Jayaraman 